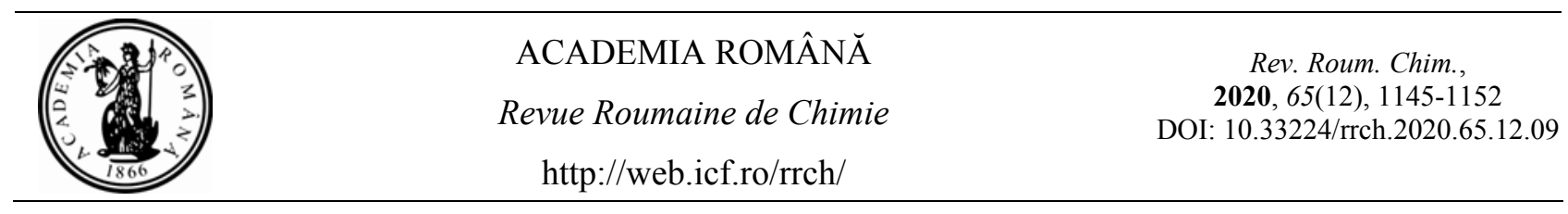

\title{
IRON(III), GOLD(III), PLATINUM(IV) AND PALLADIUM(II) TRIMETHOPRIM DRUG COMPLEXES: SYNTHESIS, SPECTROSCOPIC, MORPHOLOGICAL AND ANTICANCER ASSESSMENTS
}

\author{
Lamia A. ALBEDAIR \\ Department of Chemistry, College of Science, Princess Nourah Bint Abdulrahman University, Riyadh 11671, Saudi Arabia
}

Received October 31, 2020

Iron(III), gold(III), platinum(IV) and palladium(II) complexes of trimethoprim (TMP) drug were synthesized and well characterized using elemental analysis, conductance measurements, (UV-Vis, FTIR, ${ }^{1} \mathrm{HNMR}$ and X-ray powder diffraction) spectroscopy. The $\mathrm{Au}(\mathrm{III}), \mathrm{Pt}(\mathrm{IV})$ and $\mathrm{Pd}(\mathrm{II})$ complexes have a four coordinate geometry comprising one molecules of the TMP drug and two coordinated chloride ions, while, iron(III) complex has an octahedral geometry containing one TMP, three chloride and one coordinated water molecules. The TMP drug acts as a bi-dentate chelate towards the metal ions through the nitrogen atoms of the two amino groups attached with pyrimidine ring, this was confirmed by spectroscopic analyses with the molecular formulas $\left[\mathrm{Fe}(\mathrm{TMP}) \mathrm{Cl}_{3}\left(\mathrm{H}_{2} \mathrm{O}\right)\right] \cdot 4 \mathrm{H}_{2} \mathrm{O}$, $\left[\mathrm{Au}(\mathrm{TMP}) \mathrm{Cl}_{2}\right] \mathrm{Cl} \cdot 2 \mathrm{H}_{2} \mathrm{O},\left[\mathrm{Pt}(\mathrm{TMP}) \mathrm{Cl}_{2}\right] \mathrm{Cl}_{2} \cdot 2 \mathrm{H}_{2} \mathrm{O}$ and $\left[\mathrm{Pd}(\mathrm{TMP}) \mathrm{Cl}_{2}\right]$. The transmission electron microscopy (TEM) and XRD analyses deduced that the gold(III) complex has a nano-scale range at $10 \mathrm{~nm}$. The $\left[\mathrm{Au}(\mathrm{TMP}) \mathrm{Cl}_{2}\right] \mathrm{Cl} \cdot 2 \mathrm{H}_{2} \mathrm{O}$ complex was screened for its cytotoxicity evaluation against hepatocellular carcinoma (HepG2) and colon carcinoma (HCT-116) cell lines. It is showed that the $\mathrm{IC}_{50}$ of gold(III) complex are $7.46 \mu \mathrm{g} / \mathrm{mL}$ and $9.30 \mu \mathrm{g} / \mathrm{mL}$ against HepG2 and HCT-116 cancer cell lines, respectively.

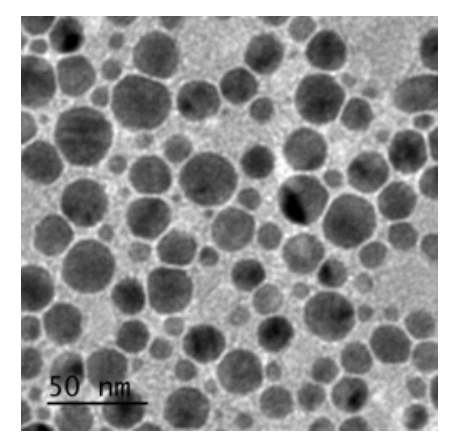

Cl. $2 \mathrm{H}_{2} \mathrm{O}$<smiles>COc1cc(Cc2cnc(Nc3nc(Cl)[nH]c3Cl)nc2Cl)cc(OC)c1OC</smiles>

\section{INTRODUCTION}

Trimethoprim is one of an important drug which has an anti-biotic and anti-parasitic activities. ${ }^{1}$ It can be used as a good chelating agent towards metal ions through the nitrogen atoms of pyrimidine ring. ${ }^{2-4}$ The mixed ligand complexes formed between trimethoprim and isoniazid towards some of transition metal ions were synthesized. ${ }^{5}$ These complexes have a coordination sites through nitrogen of pyrimidine ring of TMP and the nitrogen atom of amino group of isoniazid. ${ }^{5}$ The silver(I) complexes of trimethoprim and pyrimethamine mixed ligands have been prepared and characterized using microanalytical and spectroscopic analyses. The trimethoprim and pyrimethamine ligands act as a monodentate ligand towards $\mathrm{Ag}(\mathrm{I})$ metal ion through the nitrogen atom of pyrimidine ring. ${ }^{6}$ Silver(I) complexes of trimethoprim show stronger antibacterial activity compared to free drugs. While $\mathrm{Pt}(\mathrm{II})$ and $\mathrm{Pd}(\mathrm{II})$ complexes with both TMP and pyrimethamine

\footnotetext{
*Corresponding author: lamiaalbedair@yahoo.com
} 
ligands have a square planar geometry. ${ }^{7}$ Copper(II), zinc(II) and Ti(IV) complexes of TMP drug have been synthesized and characterized by ${ }^{13} \mathrm{C}-\mathrm{NMR}$, elemental analysis, electronic spectra and showed good antibacterial activity, the titanium(IV) and copper(II) complexes have an excellent anticancer activity. ${ }^{8}$ The $\mathrm{Cu}(\mathrm{II}), \mathrm{Zn}(\mathrm{II})$, Pt(II), $\mathrm{Ru}(\mathrm{III})$ and Fe(III) complexes of trimethoprim were prepared and characterized using elemental analysis, spectroscopic and morphology. ${ }^{3}$ The biological activity of these complexes determined by binding to calf-thymus DNA with UV-spectroscopy and cyclic voltmeter, antimicrobial activity of these complexes and antifungal activity have been evaluated and compared with TMP drug. Mn(II), Fe(III), Co(II), $\mathrm{Ni}(\mathrm{II}), \mathrm{Cu}(\mathrm{II}), \mathrm{Zn}(\mathrm{II}), \mathrm{Pb}(\mathrm{II})$ and $\mathrm{La}(\mathrm{III})$ complexes of TMP derivative were prepared and the speculated coordination were designed using different physical and chemical tool of analyses. The geometry of these complexes confirmed that the TMP derivative ligand act as a bidentate ligand. $^{9}$ In this study, the synthesis and characterization of $\mathrm{Fe}(\mathrm{III}), \mathrm{Au}(\mathrm{III}), \mathrm{Pt}(\mathrm{IV})$ and Pd(II) complexes with TMP ligand and the anticancer studies of gold(III) trimethoprim complex are presented.

\section{EXPERIMENTAL}

\section{Chemicals}

Iron(III) chloride hexahydrate, gold(III) chloride, platinum(IV) chloride and palladium(II) chloride as well as trimethoprim pure drug were received from Sigma-Aldrich Chemical Company, USA and used in the preparation without further purification.

\section{Instruments}

The type of analyses and their corresponding models can be listed as follows:

\begin{tabular}{ll}
\hline \multicolumn{1}{c}{ Type of analysis } & \multicolumn{1}{c}{ Models } \\
\hline Elemental analyses & Perkin Elmer CHN 2400 \\
Conductance & Jenway 4010 conductivity meter \\
FTIR spectra & Bruker FTIR Spectrophotometer \\
${ }^{1}$ HNMR spectra & Varian Mercury VX-300 NMR spectrometer, 300 MHz \\
Electronic spectra & UV2 Unicam UV/Vis Spectrophotometer \\
Magnetic moment & Magnetic Susceptibility Balance \\
XRD & X 'Pert PRO PANanalytical \\
TEM & JEOL 100s microscopy \\
\hline
\end{tabular}

\section{Synthesis}

The $\mathrm{Fe}(\mathrm{III}), \mathrm{Au}(\mathrm{III}), \mathrm{Pt}(\mathrm{IV})$ and $\mathrm{Pd}(\mathrm{II})$ trimethoprim complexes were synthesized by mixing $1.0 \mathrm{mmol}$ of $\mathrm{FeCl}_{3} \cdot 6 \mathrm{H}_{2} \mathrm{O}, \mathrm{AuCl}_{3}, \mathrm{PtCl}_{4}$ and $\mathrm{PdCl}_{2}$ in $30 \mathrm{~mL}$ methanol with $1.0 \mathrm{mmol}$ TMP in $30 \mathrm{~mL}$ methanol. The complex mixtures were refluxed for $\sim 4 \mathrm{hrs}$ till the colored precipitates were appeared, the solid products were filtered off and washed several times with little amounts of methanol. The solid precipitates were dried and closed in a vacuum desiccator over anhydrous $\mathrm{CaCl}_{2}$.

\section{Anticancer experiment}

Human colon carcinoma (HCT-116) and Hepatocellular carcinoma (HepG2) cells were obtained from the American Type Culture Collection (ATCC, Rockville, MD). The cells were grown on RPMI-1640 medium supplemented with $10 \%$ inactivated fetal calf serum and $50 \mu \mathrm{g} / \mathrm{mL}$ gentamycin. The cells were maintained at $37{ }^{\circ} \mathrm{C}$ in a humidified atmosphere with $5 \% \mathrm{CO}_{2}$ and were subcultured two to three times a week. A positive control containing doxorubicin drug was also tested as reference drug for comparison. Six wells were used for each concentration of the test sample. Every $24 \mathrm{~h}$ the observation under the inverted microscope was made. The number of the surviving cells was determined by staining the cells with crystal violet $^{10,11}$ followed by cell lysing using $33 \%$ glacial acetic acid and read the absorbance at $590 \mathrm{~nm}$ using ELISA reader (SunRise, TECAN, Inc, USA) after well mixing. The absorbance values from untreated cells were considered as $100 \%$ proliferation. The number of viable cells was determined using ELISA reader as previously mentioned before and the percentage of viability was calculated as $[1-(\mathrm{ODt} / \mathrm{ODc})] \times 100 \%$ where ODt is the mean optical density of wells treated with the tested sample and ODc is the mean optical density of untreated cells. The $50 \%$ inhibitory concentration $\left(\mathrm{IC}_{50}\right)$, the concentration required to cause toxic effects in $50 \%$ of intact cells, was estimated from graphic plots.

\section{RESULTS AND DISCUSSION}

\section{Elemental analysis and conductance measurements}

The yields of the solid Fe(III), Au(III), Pt(IV) and Pd(II) TMP complexes have located within 74$78 \%$ range. Trimethoprim has a seven coordination 
sites, two pyrimidinic nitrogen atoms, two $\mathrm{NH}_{2}$ group and oxygen of three methoxyl groups. The elemental analysis of an experimental data is good agreement with calculated values as mentioned in Table 1 and the proposed coordination of TMP complexes are shown in Fig. 1. The molar conductance of $\left[\mathrm{Fe}(\mathrm{TMP}) \mathrm{Cl}_{3}\left(\mathrm{H}_{2} \mathrm{O}\right)\right] \cdot 4 \mathrm{H}_{2} \mathrm{O}$, $\left[\mathrm{Au}(\mathrm{TMP}) \mathrm{Cl}_{2}\right] \mathrm{Cl} \cdot 2 \mathrm{H}_{2} \mathrm{O}, \quad\left[\mathrm{Pt}(\mathrm{TMP}) \mathrm{Cl}_{2}\right] \mathrm{Cl}_{2} \cdot 2 \mathrm{H}_{2} \mathrm{O}$ and $\left[\mathrm{Pd}(\mathrm{TMP}) \mathrm{Cl}_{2}\right]$ complexes which were dissolved in DMSO solvent $10^{-3} \mathrm{M}$ have $\Lambda_{\mathrm{m}}=14$, 47, 96, and $17 \mathrm{ohm}^{-1} \cdot \mathrm{cm}^{2} \cdot \mathrm{mol}^{-1}$ respectively, these values meaning that, the $\mathrm{Au}(\mathrm{III})$ and $\mathrm{Pt}(\mathrm{IV})$ complexes indicate there an electrolytic nature while both $\mathrm{Fe}(\mathrm{III})$ and $\mathrm{Pd}(\mathrm{II})$ complexes have a non-electrolyte properties. ${ }^{12}$

The synthesized complexes are soluble in DMSO and DMF organic solvents but insoluble in most organic solvents and water. The melting points and different colors of the solid complexes were completely different from the TMP ligand which is confirmed from the formation of the new compositions. The single melting point of the solid complexes is an indication of the purity. Elemental analysis and conductivity of the complexes indicate a 1:1 molar ratio (M:L).

Table 1

Elemental analysis and physical properties of TMP complexes

\begin{tabular}{|c|c|c|c|c|c|}
\hline Complex & Color & $\begin{array}{c}\text { Conductance } \\
\left(\mathrm{ohm}^{-1} \cdot \mathrm{cm}^{2} \cdot \mathrm{mol}^{-1}\right)\end{array}$ & Element & Calc. & Found \\
\hline \multirow{4}{*}{$\mathrm{Fe}(\mathrm{III})$} & \multirow{4}{*}{ Orange } & \multirow{4}{*}{14} & $\% \mathrm{C}$ & 30.99 & 30.92 \\
\hline & & & $\% \mathrm{H}$ & 5.20 & 5.14 \\
\hline & & & $\% \mathrm{~N}$ & 10.33 & 10.21 \\
\hline & & & $\% \mathrm{Fe}$ & 10.29 & 10.22 \\
\hline \multirow{4}{*}{$\mathrm{Au}(\mathrm{III})$} & \multirow{4}{*}{ Yellow } & \multirow{4}{*}{47} & $\% \mathrm{C}$ & 26.70 & 26.64 \\
\hline & & & $\% \mathrm{H}$ & 3.52 & 3.50 \\
\hline & & & $\% \mathrm{~N}$ & 8.90 & 8.88 \\
\hline & & & $\% \mathrm{Au}$ & 31.28 & 31.21 \\
\hline \multirow{4}{*}{$\mathrm{Pt}(\mathrm{IV})$} & \multirow{4}{*}{ Yellow } & \multirow{4}{*}{96} & $\% \mathrm{C}$ & 25.35 & 25.30 \\
\hline & & & $\% \mathrm{H}$ & 3.34 & 3.31 \\
\hline & & & $\% \mathrm{~N}$ & 8.45 & 8.42 \\
\hline & & & $\% \mathrm{Pt}$ & 29.41 & 29.35 \\
\hline & \multirow{4}{*}{ Yellow } & \multirow{4}{*}{17} & $\% \mathrm{C}$ & 35.96 & 35.91 \\
\hline & & & $\% \mathrm{H}$ & 3.88 & 3.83 \\
\hline & & & $\% \mathrm{~N}$ & 11.98 & 11.92 \\
\hline & & & $\% \mathrm{Pd}$ & 22.76 & 22.71 \\
\hline
\end{tabular}<smiles>COc1cc(Cc2cnc(Nc3cc(Cl)nc(Cl)n3)nc2O)cc(OC)c1OC</smiles>

I<smiles>COc1cc(Cc2cnc3nc2NC[P](Cl)(Cl)C3)cc(OC)c1OC</smiles>

III<smiles>COc1cc(Cc2cnc(Nc3nc(Cl)[nH]c3Cl)nc2Cl)cc(OC)c1OC</smiles>

II<smiles>COc1cc(Cc2cnc3nc2Nc2[nH]c(Cl)nc2N3)cc(OC)c1OC</smiles>

IV

Fig. 1 - Proposed coordination of iron(III), gold(III), platinum(IV) and palladium(II) TMP complexes (I, II, III, IV, respectively). 


\section{FTIR spectra}

The FTIR spectra of the TMP ligand and its iron(III), gold(III), platinum(IV) and palladium(II) complexes were scanned (Fig. 2) and assigned (Table 2). The TMP free drug has different distinguish frequencies at 3470, 3319, 2933, 2833, 1464, 1333, 1635 and $1594 \mathrm{~cm}^{-1}$ attributed to $v_{\text {as }} \mathrm{NH}_{2}, \quad v_{\mathrm{s}} \mathrm{NH}_{2}, \quad v_{\mathrm{as}} \mathrm{CH}_{3}, \quad v_{\mathrm{s}} \mathrm{CH}_{3}, \quad \delta_{\mathrm{as}} \mathrm{CH}_{3}, \quad \delta_{\mathrm{s}} \mathrm{CH}_{3}$, $v \mathrm{C}=\mathrm{N}, v \mathrm{C}=\mathrm{C}$ stretching frequencies of pyrimidine ring and trimethoxy groups respectively. The two bands of $v_{\mathrm{as}} \mathrm{NH}_{2}$ and $v_{\mathrm{s}} \mathrm{NH}_{2}$ were shifted to lower wavenumber in the spectra of the synthesized complexes and presence in the region of (3408$3184 \mathrm{~cm}^{-1}$ ), this results confirmed the coordinated of nitrogen atoms of amino group to central metal ions. $^{2-4}$ The weak to medium bands within at around of $\sim 3400 \mathrm{~cm}^{-1}$ are assigned to the stretching vibration bands of water molecules. The new absorption band detected in the spectra of complexes in the region of $520-530 \mathrm{~cm}^{-1}$ was assigned to $v(\mathrm{M}-\mathrm{N})$ and. $^{3}$ FTIR spectral data of all TMP synthesized complexes indicated that the chelating of the TMP drug towards metal ions exhibited as a bidentate ligand via the nitrogen atoms of the amino groups.

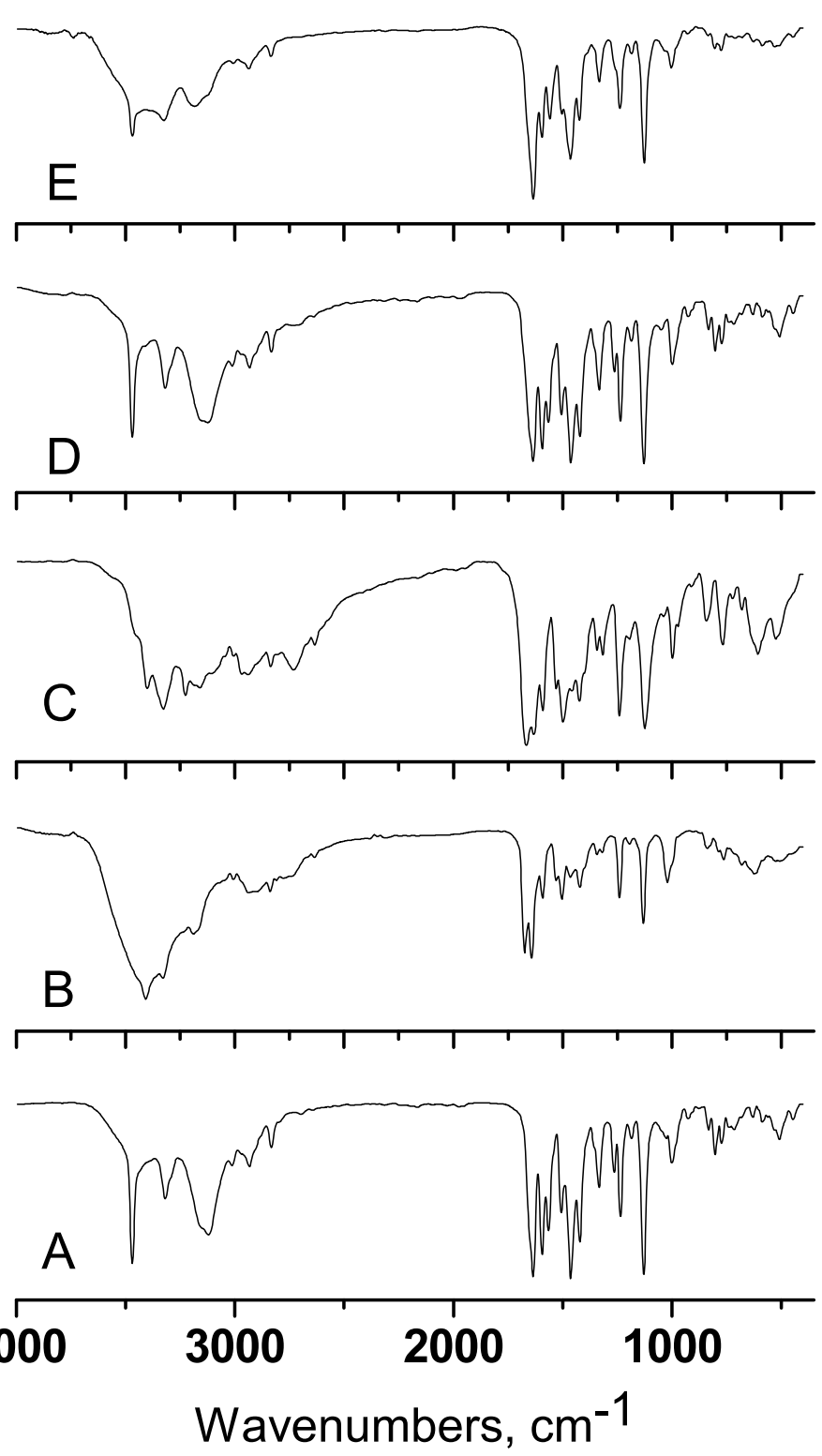

Fig. 2 - Infrared spectra of TMP free ligand and its iron(III), gold(III), platinum(IV) and palladium(II) complexes (A, B, C, D, and E, respectively). 
Table 2

Infrared spectral data $\left(\mathrm{cm}^{-1}\right)$ of TMP and its complexes

\begin{tabular}{|c|c|c|c|c|c|c|c|}
\hline \multirow[t]{2}{*}{ Compounds } & \multicolumn{7}{|c|}{ Frequencies, $\mathbf{c m}^{-1}$} \\
\hline & $\mathrm{v}_{\mathrm{as}}(\mathrm{NH})$ & $\mathrm{v}_{\mathrm{s}}(\mathrm{NH})$ & $\mathrm{v}\left(\mathrm{CH}_{3}\right)$ & $\delta\left(\mathrm{CH}_{3}\right)$ & $v(C=N)$ & $v(C=C)$ & $\mathrm{v}(\mathrm{M}-\mathrm{N})$ \\
\hline TMP & 3470 & 3319 & $\begin{array}{l}2933 \\
2833\end{array}$ & $\begin{array}{l}1464 \\
1333\end{array}$ & 1635 & 1594 & -- \\
\hline $\mathrm{Fe}(\mathrm{III})$ & 3408 & 3190 & $\begin{array}{l}3007 \\
2839\end{array}$ & $\begin{array}{l}1465 \\
1343 \\
\end{array}$ & 1643 & 1592 & 526 \\
\hline $\mathrm{Au}(\mathrm{III})$ & 3401 & 3227 & $\begin{array}{l}2940 \\
2836\end{array}$ & $\begin{array}{l}1458 \\
1343 \\
\end{array}$ & 1632 & 1591 & 525 \\
\hline $\mathrm{Pt}(\mathrm{IV})$ & 3405 & 3220 & $\begin{array}{l}2930 \\
2832\end{array}$ & $\begin{array}{l}1455 \\
1340 \\
\end{array}$ & 1637 & 1590 & 520 \\
\hline $\operatorname{Pd}(\mathrm{II})$ & 3407 & 3184 & $\begin{array}{l}2936 \\
2833\end{array}$ & $\begin{array}{l}1464 \\
1333 \\
\end{array}$ & 1635 & 1595 & 530 \\
\hline
\end{tabular}

\section{Electronic spectra and magnetic susceptibility}

The diamagnetic complexes of [Au(TMP) $\left.\mathrm{Cl}_{2}\right]$. $\mathrm{Cl} .2 \mathrm{H}_{2} \mathrm{O},\left[\mathrm{Pt}(\mathrm{TMP}) \mathrm{Cl}_{2}\right] \cdot \mathrm{Cl}_{2} \cdot 2 \mathrm{H}_{2} \mathrm{O}$ and [Pd(TMP)Cl $\left.{ }_{2}\right]$ have a square planar geometry. The electronic absorption spectrum of orange iron(III) complex contains a bands at $275,285,330 \mathrm{~nm}$, these bands are assigned to charge transfer transition from $t_{2 \mathrm{~g}} \rightarrow \pi^{*}$ and $\pi \rightarrow \mathrm{e}_{\mathrm{g}}$. The effective magnetic moment of iron(III) complex is $\left(\mu_{\text {eff }}=5.26\right.$ B.M), this meaning that the $\mathrm{Fe}(\mathrm{III})$ complex formed with an octahedral geometry. ${ }^{13}$ The electronic absorption spectrum of $\mathrm{Au}$ (III) yellow complex has three absorption bands at 325,290 and $280 \mathrm{~nm}$ attributed to ${ }^{1} \mathrm{~A}_{1 \mathrm{~g}} \rightarrow{ }^{1} \mathrm{~A}_{2 \mathrm{~g}}$, ${ }^{1} \mathrm{~A}_{1 \mathrm{~g}} \rightarrow{ }^{1} \mathrm{~B}_{1 \mathrm{~g}},{ }^{1} \mathrm{~A}_{1 \mathrm{~g}} \rightarrow{ }^{1} \mathrm{E}_{\mathrm{g}}$ and charge transfer transitions, respectively. These bands were assigned to the lowspin square planar configuration. ${ }^{14}$ The yellow color of platinum(IV) and palladium(II) complexes can be revealed to the $\mathrm{d}-\mathrm{d}$ transition bands. ${ }^{13}$ These complexes display high energy absorption band around $290 \mathrm{~nm}$ which can be traced to a typical charge transfer transitions in the complexes ${ }^{13}$ confirming the square planar geometry.

\section{4. ${ }^{1}$ HNMR spectra}

${ }^{1} \mathrm{H}-\mathrm{NMR}$ spectra and the assignments for TMP free drug and $\left[\mathrm{Au}(\mathrm{TMP}) \mathrm{Cl}_{2}\right] \mathrm{Cl} \cdot 2 \mathrm{H}_{2} \mathrm{O}$ complex are displayed in Table 3 and Fig. 3. The peaks at $\delta$ $3.40,3.52 \& 3.72,5.71 \& 6.10$ and $6.55 \& 7.51$ ppm attributed to protons of the $\mathrm{CH}_{2}$, two methoxy $\mathrm{OCH}_{3}$ groups, two $\mathrm{NH}_{2}$ groups and two protons of Ar-H group in case of trimethoprim ligand respectively. ${ }^{3}$ The protons of the two $\mathrm{NH}_{2}$ groups exhibited downfield shift to $6.20 \mathrm{ppm}$ and the other proton at $5.71 \mathrm{ppm}$ is disappeared in case of gold(III) complex. This is slightly shifted from $6.10 \mathrm{ppm}$ in the ligand to $6.20 \mathrm{ppm}$ in the complex due to the coordination of the nitrogen atoms of the two $\mathrm{NH}_{2}$ groups to the gold(III) metal ion.

\section{X-ray powder diffraction and TEM analyses}

X-ray powder diffraction spectrum of gold(III) TMP complex within $5-90^{\circ} 2 \theta$ range is presented as shown in Fig. 4, the diffraction patterns has a crystalline behavior. The Scherrer equation ${ }^{15}$ was utilized to calculate the particle size of the synthesized gold(III) complex based on the fullwidth at half-maximum. Transmission electron microscopy image of the $\left[\mathrm{Au}(\mathrm{TMP})(\mathrm{Cl})_{2}\right] \mathrm{Cl} \cdot 2 \mathrm{H}_{2} \mathrm{O}$ complex is shown in Fig. 5, the complex show a black spherical spots with $\sim 10 \mathrm{~nm}$ nano-scale.

Table 3

${ }^{1}$ HNMR spectral data $\left(\mathrm{cm}^{-1}\right)$ of TMP and its gold(III) complex

\begin{tabular}{|c|c|c|}
\hline \multirow{2}{*}{ Assignments } & \multicolumn{2}{|c|}{ Compounds } \\
\hline & TMP & Gold(III) complex \\
\hline $\mathrm{CH}_{2}$ & 3.40 & 3.48 \\
\hline $\mathrm{OCH}_{3}$ & $3.52,3.72$ & $3.59,3.74$ \\
\hline $\mathrm{NH}_{2}$ & $5.71,6.10$ & 6.20 \\
\hline Ar-H & $6.55,7.51$ & $6.62,7.46$ \\
\hline
\end{tabular}




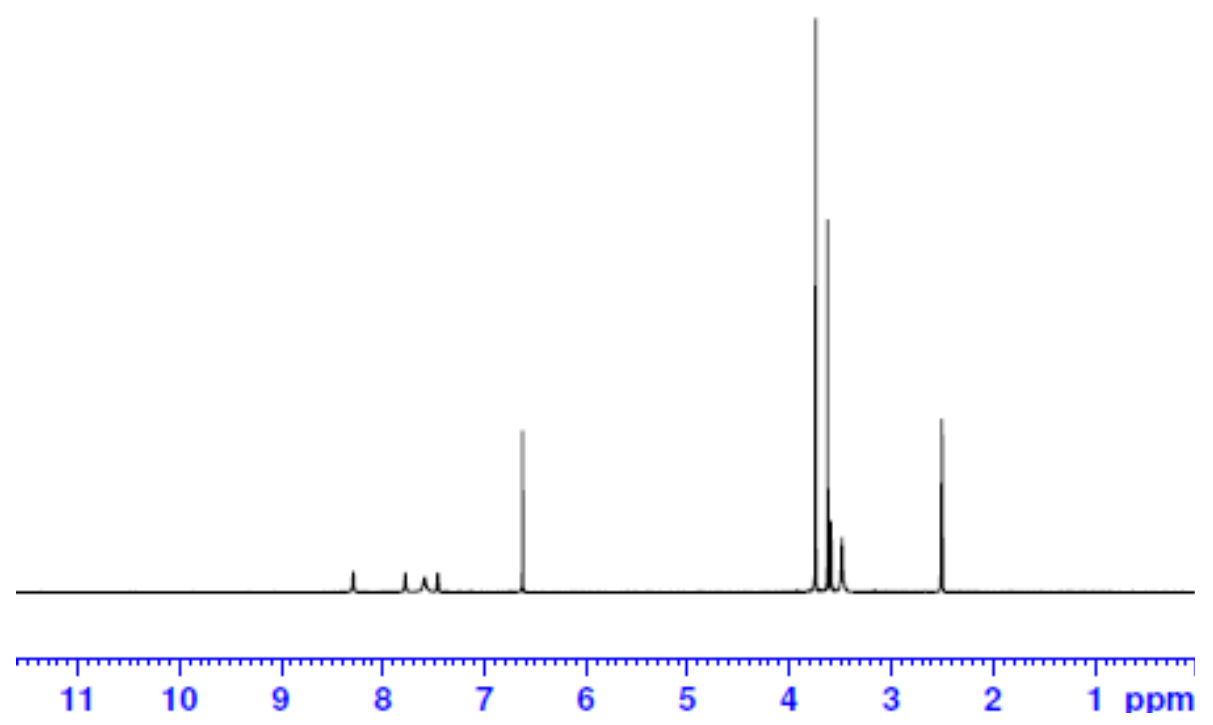

Fig. $3-{ }^{1}$ HNMR spectrum of gold(III) TMP complex.

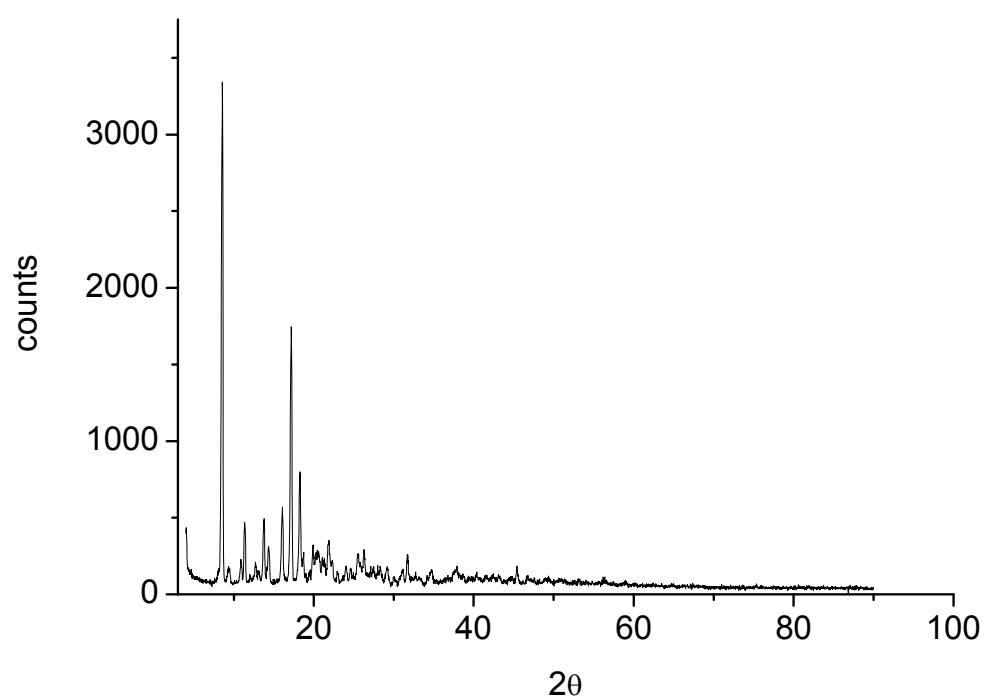

Fig. 4 - XRD spectrum of gold(III) TMP complex.

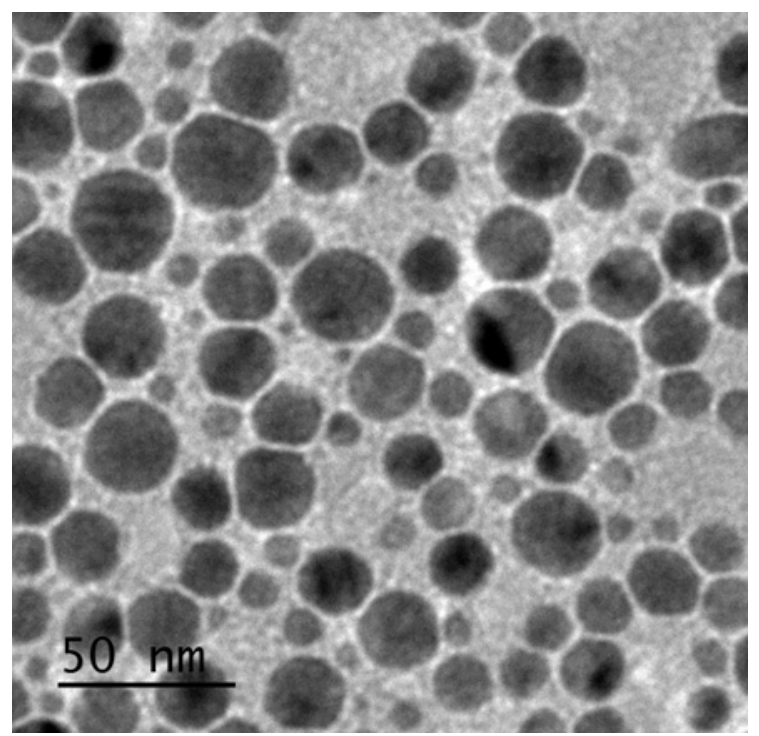

Fig. 5 - TEM image of gold(III) TMP complex. 


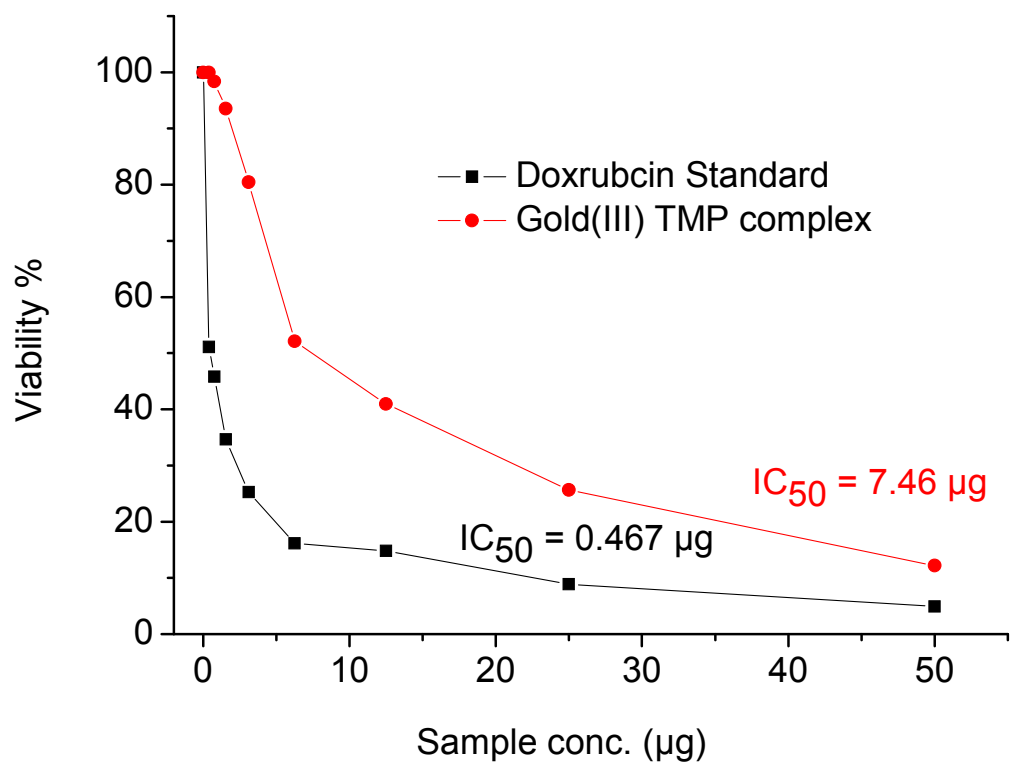

Fig. 6a-Cytotoxicity evaluation of doxorubicin standard and gold(III) TMP complex against HepG2 cell line.

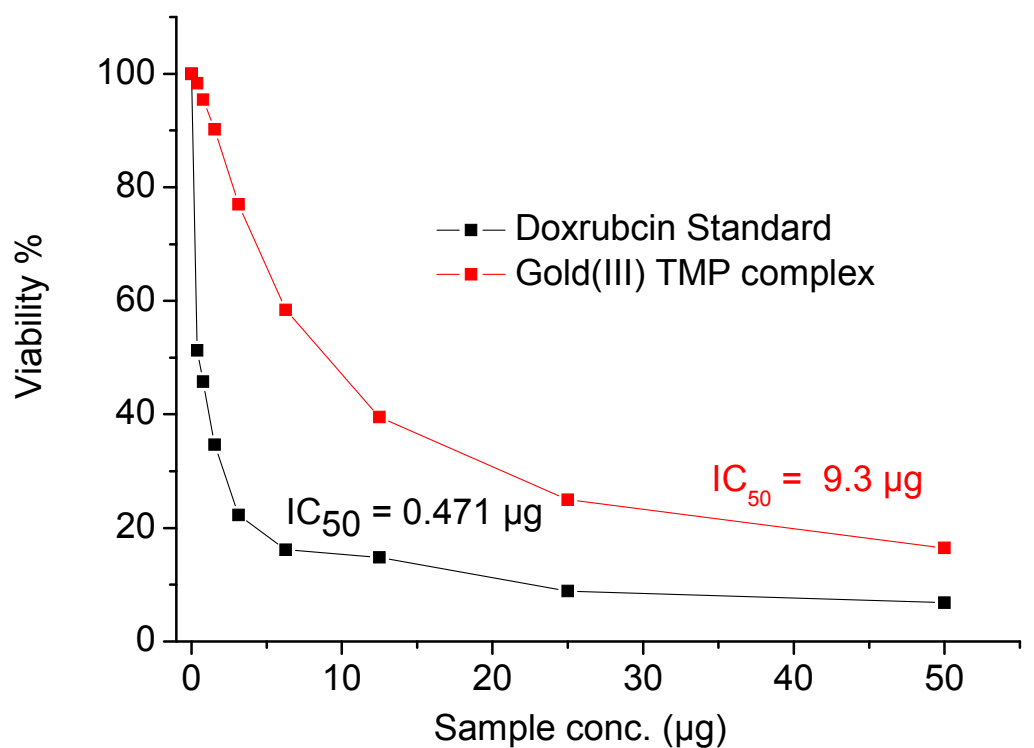

Fig. $6 \mathrm{~b}$ - Cytotoxicity evaluation of doxorubicin standard and gold(III) TMP complex against HCT-116 cell line.

\section{Anticancer assessment}

The cytotoxicity activity of the gold(III) complex against HepG2 and HCT-116 cancer cell lines were assessed (Fig. 6a,b). The half maximal inhibitory concentration $\left(\mathrm{IC}_{50}\right)$ percentage of the gold(III) complex against HepG2 and HCT-116 cancer cell lines are $7.46 \mu \mathrm{g} / \mathrm{mL}$ and $9.30 \mu \mathrm{g} / \mathrm{mL}$ respectively, in comparison with doxorubicin standard drug $(0.35 \& 0.36 \mu \mathrm{g} / \mathrm{mL}$ against HCT116 and HepG2 respectively). From this result, it can be concluded that the gold(III) TMP has a potential anticancer agent against HepG2 cell line rather than HCT-116.

\section{CONCLUSIONS}

In present investigation synthesis of $\mathrm{Fe}(\mathrm{III})$, $\mathrm{Au}(\mathrm{III}), \mathrm{Pt}(\mathrm{IV})$ and $\mathrm{Pd}(\mathrm{II})$ complexes of trimethoprim have been reported. These synthesized complexes have been characterized with the help of infrared (FT IR), electronic and ${ }^{1} \mathrm{H}-\mathrm{NMR}$ spectra, molar conductance, and magnetic susceptibility measurements at room temperature. Based on the results obtained four coordinated has been proposed for all these complexes except iron(III) complex that has an octahedral geometry. The $\mathrm{Au}(\mathrm{III})$ complex was also screened for their anticancer activities against 
HepG2 and HCT-116 cancer cell lines and the results obtained are discussed.

Acknowledgements. This research was funded by the deanship of scientific Research at Princess Nourah bint Abdulrahman University through the Fast-track Research Funding program.

\section{REFERENCES}

1. R. C. Sharma, P. P. Giri, D. Kumar and D. Neelam, J. Chem. Pharm. Res., 2012, 4, 1969-1973.

2. P. A. Ajibade and O. G. Idemudia, Bioinorg. Chem. Appl., 2013, Article ID 549549, 8 pages.

3. N. Demirezen, D. Tarınc, D. Polat, M. Cesme, A. Golcu and M. Tumer, Spectrochim. Acta Part A, 2012, 94, 243255.

4. M. Z. Ahmed and U. Habib, J. Coord. Chem., 2018, 71, 1102-1113.
5. A. F. Borowski and D. J. Cole-Hamilton, Polyhedron, 1993, 12, 1757-1765.

6. N. K. Fayad, T. H. Al-Noor and F. H Ghanim, J. Chem. Mat. Res., 2012, 2,18-29.

7. T. H. Al-Noor, A. T. AL-Jeboori and M. R. Aziz, J. Chem. Mat. Res., 2013, 3, 14-125.

8. A. El-Shekeil, A. Omer, S. Al-Aghbari and O. AlShuja'a, J. Cancer Res. Updates, 2013, 2, 14-20.

9. A. M. A. Alaghaz, R. S. Farag, M. A. Elnawawy and A. D. A. Ekaw, Int. J. Sci. Res. (IJSR), 2016, 5, 1220-1229.

10. T. Mosmann, J. Immunol. Methods, 1983, 65, 55-63.

11. V. Gangadevi and J. Muthumary, African J. Biotechn., 2007, 6, 1382-1386.

12. G. B. Deacon and R. J. Philips, Coord. Chem. Rev., 1980, 33, 227-232.

13. A. B. P. Lever, "Inorganic Spectroscopy", 2nd edition, Elsevier Science Publisher, Amsterdam, 1984.

14. J. M. Tunney, A. J. Blake, E. S. Davies, J. McMater, C. Wilson and C. D. Garner, Polyhedron, 2006, 25 591-595.

15. B. D. Cullity and S. R. Stock, "Elements of X-ray Diffraction", $3^{\text {rd }}$ edition, New York: Prentice Hall, 2001, p. 389. 